\title{
Variation in Phytate Accumulation in Common Bean (Phaseolus vulgaris L.) Fruit Explants
}

\author{
Cileide Maria Medeiros Coelho ${ }^{1 *}$, Cláudia Mattos Bellato ${ }^{2}$, Andréia Karime Marcelino \\ Garcia $^{3}$, Victor Alexandre Vitorello ${ }^{2}$ and Ricardo Antunes Azevedo ${ }^{3}$ \\ ${ }^{1}$ Centro de Ciências Agroveterinárias - CAV; Universidade do Estado de Santa Catarina - UDESC; C. P. 281; \\ a2cmm@cav.udesc.br; 88.502-970; Lages - SC - Brasil. ${ }^{2}$ Laboratório de Biologia Celular e Molecular; Centro de \\ Energia Nuclear na Agricultura (CENA); Universidade de São Paulo - USP; C. P. 96; 13400-970; Piracicaba - SP \\ - Brasil. ${ }^{3}$ Escola Superior de Agricultura Luiz de Queiroz - ESALQ; Universidade de São Paulo - USP; C. P. 83; \\ 13400-970; Piracicaba - SP - Brasil
}

\begin{abstract}
The in vitro synthesis of phytate was studied in common bean fruit explants. Different concentrations of sucrose; phosphorus (P); myo-inositol; abscisic acid (ABA); glutamine and methionine, were tested. Fixed concentrations of these compounds were tested at different periods (0,3,6 and 9 days). Variation in phytate coincided with different concentrations of sucrose, myo-inositol, $P$ and ABA for the duration tested. These compounds caused an accumulation of phytate and were more effective in the presence of myo-inositol and $P$. The accumulation of $P$ varied less than phytate for the different treatments tested in vitro. In conclusion, $P$, sucrose, ABA, and myo-inositol caused an increase in the phytate of bean seed, showing that it could be possible to alter its content by culturing bean fruit explants in vitro.
\end{abstract}

Key words: Abscisic acid; glutamine; phosphorus; phytic acid; sucrose

\section{INTRODUCTION}

The stored phosphorus $(\mathrm{P})$ in the form of phytate (myo-inositol hexakisphosphate - $\mathrm{InsP}_{6}$, phytic acid) occurs during the development of common bean (Phaseolus vulgaris) fruit and depends on the supply of organic $\mathrm{P}$ from other parts of the plant and on the assimilation of myo-inositol or glucose6P. Phytate is deposited in the bean seeds within single-membrane storage organelles, referred to as protein bodies. These are mostly complexed with minerals ( $\mathrm{K}, \mathrm{Mg}, \mathrm{Ca}, \mathrm{Fe}$ and $\mathrm{Zn}$ ) and are known as phytin (Reddy et al., 1989). Phytate or phytic acid represents from 65 to $85 \%$ of the total seed $\mathrm{P}$ (Reddy et al., 1989). As a polyanion, phytate is an effective chelator of positively charged molecules and has the potential to form stable insoluble complexes with minerals and proteins. These complexes confer to phytate its notorious antinutritional properties, which are particularly important for the humans and nonruminants, such as poultry, swine and fish that lack the hydrolytic enzyme phytase in their digestive tract and excrete a large fraction of these phytin salts (Cheryan, 1980). Moreover, the amount of phytate that breaks down during the storage of common beans appears to be the most important trait in the development of the hard to cook (HTC) phenomenon (Coelho et al., 2007a).

On the other hand, phytate is generally considered

\footnotetext{
${ }^{*}$ Author for correspondence
} 
an important source of nutrients during bean seed germination, which provides inorganic phosphate, minerals and myo-inositol to the growing seedling, although it is not apparently required at the typical levels (Raboy et al., 2001). Furthermore, a diet rich in phytic acid may also have a beneficial role in human health, as an antioxidant and anticarcinogen (Zhou and Erdman, 1995).

Studies have been conducted with phytate to reduce the levels of InsP6 in the seeds to improve iron and zinc availability in food (Lucca et al., 2001). For instance, studies were carried out with maize (Zea mays) mutants, where loss of function mutations at two loci, low phytic acid 1-1 (lpal-1) and low phytic acid 2-1 (lpa2-1), caused a reduction of InsP6 by about two-third and an increase in inorganic phosphorus by a molarequivalent when compared with the wild type. In lpa2-1 maize mutant, Ins $P 6$ was reduced by around 50\%, while inorganic phosphorus and inositol phosphate contents increased when compared to that of the wild type (Larson et al., 1998; Raboy et al., 2000; Raboy et al., 2001).

Another approach to study phytate would be the identification and regulation of the physiological and biochemical mechanisms that are involved or that control phytic acid accumulation and their relationships with other inositol and phosphorus pools. Essentially, two types of studies could be performed: the elucidation of the exact metabolic pathway of phytic acid, and the understanding of the mechanisms that regulate phytic acid accumulation. However, when the pathway is considered, several points of this cascade are still not well defined due to multiple, simultaneous and non-linear pathways that lead to phytic acid synthesis (Coelho and Vitorello, 2002; Shi et al., 2003; Stevenson-Paulik et al., 2002).

Some reports have provided important evidences to suggest that D-myo-inositol-3-phosphate synthase (MIPS, E.C. 5.5.1.4) plays a regulatory role in phytate synthesis in developing common bean seeds (Coelho et al., 2005b; Hegeman et al., 2001; Yoshida et al., 1999; Coelho et al., 2007b). Moreover, recent studies showed a possible control point in the conversion of inositol pentakisphosphate to inositol hexakisphosphate (Coelho et al., 2005b). Several other studies have shown that the accumulation of phytic acid oscilates in response to the variation of $\mathrm{P}$ supplied during seed development (Coelho et al., 2002; Raboy and Dickinson, 1984; Raboy and Dickinson, 1993). The pathway of phytate synthesis begin with myo-inositol-monophosphate, which is produced if both enzymes, MIPS and myo-inositol-kinase, act upon glucose-6-P and myo-inositol, respectively. Moreover, myoinositol-monophosphate is a precursor of phytate synthesis since it is a non-reversible reaction (Loewus and Murthy, 2000).

Considering that sucrose and abscisic acid (ABA) may affect the synthesis of storage compounds in seeds and MIPS expression, a possible alteration in the phytate synthesis may occur since the content of myo-inositol-monophosphate will also be changed (Yoshida et al., 2002; Yoshida et al., 1999).

Other possible regulatory steps of phytate synthesis might involve protein synthesis due to negative correlations between the content of proteins and phytate in grains (Raboy, 1990) and most of the phytic acid is deposited as a mixture and packaged into discrete, membrane bound inclusions referred as globoids (Lott et al., 1985).

Due to many factors involved in phytate accumulation, an in vitro system would be an appropriate way to study phytic acid synthesis. Soybean fruit explants cultured in vitro showed alterations in their protein patterns and free amino acids of the cotyledons when methionine and different sources of nitrogen were provided (Mosquim and Sodek, 1991; Mosquim and Sodek, 1992). Therefore, based upon this work, an in vitro test of cultured common bean fruit explants was conducted with the objective to alter phytate and protein synthesis. This system allowed the elimination of the complex interaction between the fruit and the plant and altered the availability of components involved in the synthesis of both phytate and protein.

\section{MATERIAL AND METHODS}

\section{Growth of plants}

Seeds of a commercial line of common bean (Phaseolus vulgaris L.), Una variety, were supplied by the Experimental Research Station of the Instituto Agronômico de Campinas - IAC, in Capão Bonito, SP, Brazil. Plants were grown in a greenhouse in 10-L pots containing $8 \mathrm{~L}$ of a $4: 1$ (v/v) mixture of soil and commercial substrate. A dystrophic soil was collected and amended with lime at $3.8 \mathrm{~g} . \mathrm{dm}^{-3}$, according to chemical analysis to reach a base saturation of about $70 \%$. Prior to planting, phosphorus, nitrogen and potassium were 
applied to the mixture at a rate of 37,17 and 70.4 mg. $\mathrm{dm}^{-3}$ of $\mathrm{P}, \mathrm{N}$ and $\mathrm{K}$, respectively. At 25 and 35 days after planting (DAP), each pot received 27.5 $\mathrm{mg} \mathrm{N} \cdot \mathrm{dm}^{-3}$. The experimental design was a complete randomized block with one variety, four replicates and one harvest time.

All the flowers were labeled with their date of anthesis and pods were collected at one age from independent plants. Each individual plant provided fruit explants (bean pods with immature seeds and a short piece of stem) and was maintained under greenhouse conditions for developmental in situ analysis.

To evaluate the synthesis of phytate, two independent experiments were conducted: 1) altering the different concentrations of compounds (sucrose; phosphorus (P); myo-inositol; abscisic acid (ABA); glutamine and methionine) that were directly and indirectly involved in phytate synthesis, and 2) testing various periods of growth on phytate synthesis at a fixed concentrations of the mentioned compounds.

\section{Experiment 1}

Growth of common bean fruit explant with different compounds at varied concentrations: The culture system used was according to Mosquin and Sodek (1991) including the basal culture medium (BCM), which was used to cultivate the bean fruit explants. The BCM contained the macronutrients (Chandler et al., 1983) together with Fe-EDTA and micronutrients (Murashige and Skoog 1962). Immature fruits containing seeds (approximately $150 \mathrm{mg}$ of fresh weight) obtained from the greenhouse were cultured for 12 days in BCM amended with one of the following treatments, i.e., compounds at different $\mathrm{mM}$ concentrations: Sucrose at $0,40,80,160$ and 320; Phosphorus at $0,3,6,12$ and 24; Myo-inositol at 0, 1, 5, 10 and 20; Abscisic acid (ABA) at 0, 0.05, 0.10, 0.125 and 0, 150; Glutamine at 0, 10, 20, 40 and 80, and Methionine at $0,5,10,15$ and 25. Each concentration tested had three repetitions.

\section{Experiment 2}

Growth culture of bean fruit explants at different periods: Culture of fruit explants obtained from the greenhouse was conducted separately with BCM amended with one of the following compounds at a fixed concentration of sucrose $(160 \mathrm{mM}) ; 10 \mathrm{mM}$ myo-inositol; $12 \mathrm{mM}$ phosphorus and $0.125 \mathrm{mM} \mathrm{ABA}$ for $0,3,6$ and 9 days. Each period tested had three replicates.
These concentrations were chosen based on the highest accumulation of phytate observed in preliminary tests and on results reported by Coelho et al. (2002b).

\section{Controls}

The following controls were conducted for both the experiments. $\mathrm{CT}_{0}$ : fruit explants were harvested before initiating in vitro culture (at zero time). The following treatments were explants maintained in the greenhouse for a determined period followed by in situ analysis: $\mathrm{CT}_{3}: 3$ days; $\mathrm{CT}_{6}: 6$ days; $\mathrm{CT}_{9}: 9$ days, and $\mathrm{CT}_{12}: 12$ days.

\section{Seed analysis}

Seeds obtained from the Experiments 1 and 2 were separated from the bean pod and lyophilized. The weight and the number of the seeds were documented and finely ground in the presence of liquid nitrogen. The following parameters were analyzed: total phosphorus $(\mathrm{P})$ and the content of total protein and phytate.

\section{Determination of total phosphorus (P)}

The content of $\mathrm{P}$ was determined colorimetrically following nitric/perchloric acid digestion, using the metavanadate method, which was based on the formation of a yellow vanadomolybdophosphoric complex (Bernhart and Wreath, 1955).

\section{Determination of phytic acid}

The method of Latta and Eskin (1980) was employed to determine the phytic acid. A $500 \mathrm{mg}$ sample was extracted with $20 \mathrm{~mL}$ of $2.4 \% \mathrm{HCl}$ $(0.65 \mathrm{~N})$ for $2 \mathrm{~h}$ at room temperature on a rotatory shaker $(200 \mathrm{rpm})$. The extract was centrifuged $10,000 \mathrm{~g}, 15 \mathrm{~min})$ and the supernatant was decanted and filtered through Whatman number 1 filter paper. A 3-mL aliquot of the filtrate was diluted to $18 \mathrm{~mL}$ with distilled water and the diluted sample was passed through a 200-400 mesh AG1-X8 chloride anion exchange resin, taking care that no more than $3 \mathrm{mg}$ phytate per 0.5 $\mathrm{g}$ of resin was applied. Inorganic phosphorus was eluted with $0.07 \mathrm{M} \mathrm{NaCl}$ followed by elution of phytate with $0.7 \mathrm{M} \mathrm{NaCl}$. Phytate was determined colorimetrically based on the pink color of the Wade reagent, which was formed upon the reaction of ferric ion and sulfosalicylic acid, and had an absorbance maximum at $500 \mathrm{~nm}$.

Total nitrogen determination (total protein)

Total protein content was determined by total $\mathrm{N}$ 
content of the sample, where $\%$ Protein $=\mathrm{N}$ content $(\%) \times 6.25$. Samples $(200 \mathrm{mg})$ were placed in $75-\mathrm{mL}$ digestion tubes and $6 \mathrm{~mL}$ of digestion mixture, which consisted of concentrated sulfuric acid, $30 \%$ hydrogen peroxide, $14 \%$ lithium sulfate and $42 \%$ selenium, was added to each sample. The samples were placed in a digestion block at $250{ }^{\circ} \mathrm{C}$ until samples became clear. Samples were diluted with water to a final volume of $75 \mathrm{~mL}$. The $\mathrm{N}$ content of the samples was quantified according to Parkinson and Allen (1975).

\section{RESULTS}

\section{Accumulation of the seed dry matter}

The growth of seeds from the common bean fruit explants cultured for 12 days was determined by the accumulation of dry matter. Data for the dry matter of the seeds before and after the culture at different concentrations of sucrose, myo-inositol, phosphorus $(\mathrm{P})$, abscisic acid (ABA), glutamine and methionine are shown in Table 1. The accumulation of dry matter from in vitro culture of fruit explants was different when compared to that for seeds from in situ culture $\left(\mathrm{CT}_{12}, 0.183\right.$ g.seed $^{-}$ $\left.{ }^{1}\right)$. A considerable augmentation in the dry matter of the seeds was observed due to the increase in concentrations of sucrose, phosphorus and myoinositol. Increases of 42, 127, 49, $50 \mathrm{mg} / \mathrm{seed}$ were observed for the highest concentrations of sucrose, phosphorus, myo-inositol and glutamine, respectively, when compared with their corresponding $0 \mathrm{mM}$ levels (Table 1 ).

The accumulation of dry matter of the seeds at 24 mM P $(0.203 \mathrm{~g} / \mathrm{seed})$ was higher than that for in situ culture at 12 days $\left(\mathrm{CT}_{12} 0.183 \mathrm{~g} / \mathrm{seed}\right)$ and triggered seeds to accumulate 13 times more dry matter over a 12 day period (Table 1). At $320 \mathrm{mM}$ sucrose, the accumulation of dry matter (42 $\mathrm{mg} / \mathrm{seed}$ ) was higher than reported by Mosquim and Sodek (1991), who observed a $26 \mathrm{mg} / \mathrm{seed}$ increase for soybean fruit explants cultured at 46 to $292 \mathrm{mM}$ of sucrose. These results indicated that the common bean seeds underwent considerable development, which was higher than other explant cultures reported in the literature, such as soybean and pea (Barratt, 1986; Mosquim and Sodek, 1991; Mosquim and Sodek, 1992).

The accumulation of dry matter observed at the end of the 9 days of in vitro culture (Table 2) and in the presence of sucrose at the initial time $\left(\mathrm{CT}_{0}\right)$ was around a three-fold increase. This was higher than that obtained when the concentration of sucrose varied (from $0 \mathrm{mM}$ to $320 \mathrm{mM}$ ) for the 12day culture (Table 1), which caused a 1.47 -fold increase in the dry matter. This indicated that the culture period caused a greater effect on the development of the seed rather than the concentration of sucrose tested.

Regarding the growth period (Table 2), no considerable effect was observed between the treatments for the seeds cultured in vitro for up to 9 days. However, the dry matter obtained for the in vitro sucrose treatment was approximately 1.4-fold lower when compared to that of in situ up to 9 days.

\section{Phytate, phosphorus and protein seed accumulation}

The accumulation of phytate increased based on the given concentration of the compounds, and occurred mainly for the treatment 4 (T4) with myo-inositol, phosphorus, sucrose and ABA at 10, 12, 160 and $0.125 \mathrm{mM}$, respectively (Fig. 1A, B). However, a decrease in the phytate accumulation was found above these concentrations, with the exception of phosphorus, in which the accumulation was not altered (Fig. 1A). Overall, myo-inositol caused the greatest effect on the accumulation of phytate (Fig. 1A). On the other hand, the different concentrations of methionine caused an oscillation in the accumulation of phytate, while glutamine above $10 \mathrm{mM}$ caused a decrease in phytate accumulation (Fig. 1B).

An increase of $0.35 \mathrm{mg} / \mathrm{seed}$ of $\mathrm{P}$ was found after adding different concentrations of $\mathrm{P}$ in the culture medium $\left(T_{1}\right.$ to $\left.T_{5}\right)$ (Fig. 1C). For other treatments, only myo-inositol and glutamine, both at $10 \mathrm{mM}$, caused a considerable accumulation of $\mathrm{P}$ (Fig. 1C, 1D).

The increase in the accumulation of seed proteins with $\mathrm{P}$, myo-inositol and sucrose treatments was very similar, i.e., approximately $10 \mathrm{mg} / \mathrm{seed}$ when compared to the highest concentrations of the respective treatments (Fig. 1E). On the other hand, no considerable alteration in the accumulation of seed proteins was found for other treatments (glutamine, methionine and ABA) (Fig. 1F). When the values for the treatments of the in vitro culture were compared with those of the control $\mathrm{CT}_{0}$ $(0.095 \mathrm{mg} / \mathrm{seed})$ and $\mathrm{CT}_{12}(1.062 \mathrm{mg} / \mathrm{seed})$ from the in situ culture, only phytate accumulated at a large proportion in the presence of myo-inositol and $\mathrm{P}$, reaching $1.65 \mathrm{mg} / \mathrm{seed}$ and $1.1 \mathrm{mg} / \mathrm{seed}$, respectively (Fig. 1A, B). The accumulation of $\mathrm{P}$ 
in seeds from in vitro culture was similar to that found for the control $\mathrm{CT}_{0}(0.165 \mathrm{mg} / \mathrm{seed})$ and $\mathrm{CT}_{12}(0.781 \mathrm{mg} / \mathrm{seed})$ for the in situ culture. In the presence of myo-inositol and $\mathrm{P}$, phytate accumulated to $0.75 \mathrm{mg} / \mathrm{seed}$ and $0.8 \mathrm{mg} / \mathrm{seed}$, respectively. These values were similar to that found for $\mathrm{CT}_{12}$ (Fig. 1C, D).

Table 1 - Dry matter of common bean (Phaseolus vulgaris L.) of seeds (Una variety) cultured in vitro and in situ for 12 days. Seeds were cultured in vitro in basal medium amended with one of the following compounds at different concentrations: phosphorus, myo-inositol, abscisic acid, glutamine and methionine. Seeds cultured at zero time $\left(\mathrm{CT}_{0}\right)$ had a dry matter seed weight of $0.014 \pm 0.007$. Seeds from in situ culture, after 12 days $\left(\mathrm{CT}_{12}\right)$, had dry matter seed weights of $0.183 \pm 0.014$. (*standard error of mean, $n=3$ ).

\begin{tabular}{|c|c|c|c|c|c|}
\hline \multicolumn{2}{|r|}{ Sucrose } & \multicolumn{2}{|r|}{ Phosphorus } & \multicolumn{2}{|r|}{ Myo-inositol } \\
\hline$(\mathrm{mM})$ & mass (g/seed) & $(\mathrm{mM})$ & mass $(\mathrm{g} / \mathrm{seed})$ & \multicolumn{2}{|c|}{$(\mathrm{mM}) \quad$ mass $(\mathrm{g} / \mathrm{seed})$} \\
\hline 0 & $0.089 \pm 0.019 *$ & 0 & $0.076 \pm 0.022$ & 0 & \\
\hline 40 & $0.086 \pm 0.008$ & 3 & $0.108 \pm 0.016$ & 1 & $0.111 \pm 0.013$ \\
\hline 80 & $0.093 \pm 0.018$ & 6 & $0.114 \pm 0.018$ & \multicolumn{2}{|r|}{$0.105 \pm 0.015$} \\
\hline 160 & $0.101 \pm 0.011$ & 12 & $0.098 \pm 0.015$ & \multicolumn{2}{|r|}{$0.114 \pm 0.029$} \\
\hline 320 & $0.131 \pm 0.016$ & 24 & $0.203 \pm 0.014$ & 20 & $0.131 \pm 0.023$ \\
\hline & Abscisic acid & & Glutamine & \multicolumn{2}{|r|}{ Methionine } \\
\hline$(\mathrm{mM})$ & mass (g/seed) & $(\mathrm{mM})$ & mass (g/seed) & \multicolumn{2}{|r|}{ mass (g/seed) } \\
\hline 0 & $0.103 \pm 0.011$ & 0 & $0.085 \pm 0.015$ & 0 & $0.085 \pm 0.018$ \\
\hline 0.050 & $0.119 \pm 0.028$ & 10 & $0.146 \pm 0.016$ & 5 & $0.131 \pm 0.017$ \\
\hline 0.100 & $0.118 \pm 0.031$ & 20 & $0.139 \pm 0.014$ & 10 & $0.130 \pm 0.013$ \\
\hline 0.125 & $0.116 \pm 0.042$ & 40 & $0.128 \pm 0.013$ & 15 & $0.128 \pm 0.014$ \\
\hline 0.150 & $0.106 \pm 0.022$ & 80 & $0.135 \pm 0.026$ & 25 & $0.104 \pm 0.018$ \\
\hline
\end{tabular}

Table 2 - Dry matter of common bean (Phaseolus vulgaris L.) seeds (Una variety) cultured in vitro and in situ (control) for 0, 3, 6 and 9 days. Seeds were cultured in vitro in basal medium amended with fixed concentration of compounds: phosphorus $(12 \mathrm{mM})$, myo-inositol $(10 \mathrm{mM})$, abscisic acid $(0.125 \mathrm{mM})$, glutamine $(80 \mathrm{mM})$ and methionine $(22 \mathrm{mM}) .($ *standard error of mean, $\mathrm{n}=3)$.

\begin{tabular}{lcccc}
\hline Culture & Sucrose & Phosphorus & Myo inositol & Abscisic acid \\
\hline (days) & $\begin{array}{c}\text { Mass } \\
(\mathrm{g} / \mathrm{seed})\end{array}$ & $\begin{array}{c}\text { Mass } \\
(\mathrm{g} / \mathrm{seed})\end{array}$ & $\begin{array}{c}\text { Mass } \\
(\mathrm{g} / \mathrm{seed})\end{array}$ & $\begin{array}{c}\text { Mass } \\
(\mathrm{g} / \mathrm{seed})\end{array}$ \\
\hline 0 & $0.043 \pm 0.0015^{*}$ & $0.042 \pm 0.0016$ & $0.042 \pm 0.0014$ & $0.045 \pm 0.0081$ \\
3 & $0.063 \pm 0.0059$ & $0.066 \pm 0.0058$ & $0.064 \pm 0.0022$ & $0.078 \pm 0.0064$ \\
6 & $0.081 \pm 0.0071$ & $0.088 \pm 0.0011$ & $0.087 \pm 0.0042$ & $0.086 \pm 0.0068$ \\
9 & $0.123 \pm 0.0092$ & $0.091 \pm 0.0085$ & $0.093 \pm 0.0072$ & $0.111 \pm 0.0099$ \\
\hline
\end{tabular}

\begin{tabular}{lccc}
\hline Culture & Glutamine & Methionine & in situ (Control) \\
\hline (days) & $\begin{array}{c}\text { Mass } \\
(\mathrm{g} / \mathrm{seed})\end{array}$ & $\begin{array}{c}\text { Mass } \\
(\mathrm{g} / \mathrm{seed})\end{array}$ & $\begin{array}{c}\text { Mass } \\
(\mathrm{g} / \mathrm{seed})\end{array}$ \\
\hline 0 & $0.044 \pm 0.0016$ & $0.046 \pm 0.0011$ & $0.047 \pm 0.0031$ \\
3 & $0.065 \pm 0.0026$ & $0.062 \pm 0.0064$ & $0.087 \pm 0.0056$ \\
6 & $0.089 \pm 0.0081$ & $0.093 \pm 0.0069$ & $0.166 \pm 0.0082$ \\
9 & $0.091 \pm 0.0078$ & $0.099 \pm 0.0065$ & $0.172 \pm 0.0089$ \\
\hline
\end{tabular}

The accumulation of protein seed in the in vitro culture experiment (average of $25 \mathrm{mg} / \mathrm{seed}$ ) (Fig. $1 \mathrm{E}, \mathrm{F})$ was lower in all treatments when compared to that of the control $\mathrm{CT}_{0}(14.22 \mathrm{mg} / \mathrm{seed})$ and $\mathrm{CT}_{12}(41.22 \mathrm{mg} / \mathrm{seed})$ from the in situ culture (data not shown). This finding was probably due to the amount of the accumulated dry matter observed for the seeds cultured in vitro, which was $60.6 \%$ lower than that found for those cultured in situ for the majority of the treatments (Table 1). If the amount of phytate accumulated was compared to that of $\mathrm{P}$, the data showed that overall, $\mathrm{P}$ was mainly altered in the phytate form rather than in the total P.

By altering the period of the in vitro culture $(0,3$, 6 and 9 days), the increased amount of phytate was 
similar, at 9 days, to that of the in situ culture in the presence of sucrose, phosphorus, myo-inositol and ABA. On the other hand, glutamine and methionine had the least effect on phytate accumulation in the seeds since they caused an increase only up to 6 days followed by a constant level up to nine days in culture (Fig. 2A, B). Phosphorus accumulated in the seeds as the period of the in vitro culture increased for the first 6 days of all the treatments, followed by a constant level after this period, with the exception of sucrose and ABA, which caused an increase in $\mathrm{P}$ levels up to 9 days (Fig. 2C, D).

When compared to the in situ culture, the accumulation of $\mathrm{P}$ observed in the seeds from in vitro culture was lower (50\%), starting at 3 days and remained lower for all the treatments. This low $\mathrm{P}$ accumulation was due to the reduced accumulation of dry matter found for in vitro culture (Table 2). The accumulation of phytate in the seed was greater in both experiments 1 and 2, for P, myo-inositol, sucrose and ABA. These results suggested an effect of these compounds on the synthesis of phytate.

Seed proteins were accumulated in a similar manner to that observed for $\mathrm{P}$ during the in vitro culture (Fig. 2E, F). This mainly occurred after the addition of glutamine, methionine and $\mathrm{ABA}$, which caused an increase in the protein levels up to the sixth day and remained constant till the end of the experiment (9 days) (Fig. 2E, F). After 6 days, a slight increase in the accumulation of seed proteins, approximately $7.5 \mathrm{mg} / \mathrm{seed}$, was observed in the presence of sucrose, $\mathrm{P}$ and myoinositol at 9 days of in vitro culture. When compared to in situ conditions, the accumulation of seed proteins from in vitro culture was lower from the third to the ninth day. This value was approximately $18 \mathrm{mg} / \mathrm{seed}$ and corresponded to around $50 \%$ of the value found for the in situ conditions. This percentage was due to the dry matter accumulated, which was 50\% lower than that observed for in situ conditions (Table 2).

\section{DISCUSSION}

The in vitro system used for common bean fruit explants showed a considerable alteration in the accumulation of the parameters tested, total phosphorus $(\mathrm{P})$, total protein content and phytate in seeds after the addition of $\mathrm{P}$, sucrose, myo- inositol and ABA to the culture medium. No effect on the seeds was observed with glutamine and methionine for the accumulation of these parameters. Overall, the variation found for the accumulation of phytate concurred in the presence of sucrose, myo-inositol, $\mathrm{P}$ and ABA after altering their concentrations as well as with the period of in vitro culture (Fig. 1A, B and 2A, B). Moreover, the accumulation of phytate was higher mainly after adding myo-inositol and $\mathrm{P}$ to the medium when compared to that for the in situ conditions (Fig. 2A). Studies conducted in situ have shown an increase in the accumulation of seed phytate in response to a higher availability of $\mathrm{P}$ (Coelho et al., 2002; Raboy and Dickinson, 1993). The addition of myo-inositol to the medium can provide monophosphate myo-inositol through the activity of myo-inositol kinase, or it can be supplied by de novo synthesis from glucose-6phosphate via MIPS activity. It can also be recycled from the stored or translocated forms, since myo-inositol-1P is produced by MIPS and/or myo-inositol-kinase enzymes for which myoinositol is a substrate (Loewus and Murthy, 2000). In the present study, this substrate might have caused an increase in the expression of these enzymes and consequently an increase of the final product, phytate, in the seeds since the reaction forming myo-inositol-1P was irreversible.

The positive response of the seed to accumulate phytate in the presence of sucrose and ABA might be due to the fact that both could affect the synthesis of the stored compounds in the seeds (Coelho et al., 2005b) and the MIPS expression. Moreover, a possible alteration of the synthesis of phytate might occur since the content of myoinositol-1P would also be changed (Yoshida et al., 2002; Yoshida et al., 1999).

Values observed for phytate and $\mathrm{P}$ exhibited an interesting relationship since the accumulation of $\mathrm{P}$ varied less than the increase of phytate in the different treatments tested in vitro. Seeds accumulated $\mathrm{P}$ mainly due to the increase of the concentration of $\mathrm{P}$ in the medium (Fig. 1C). 

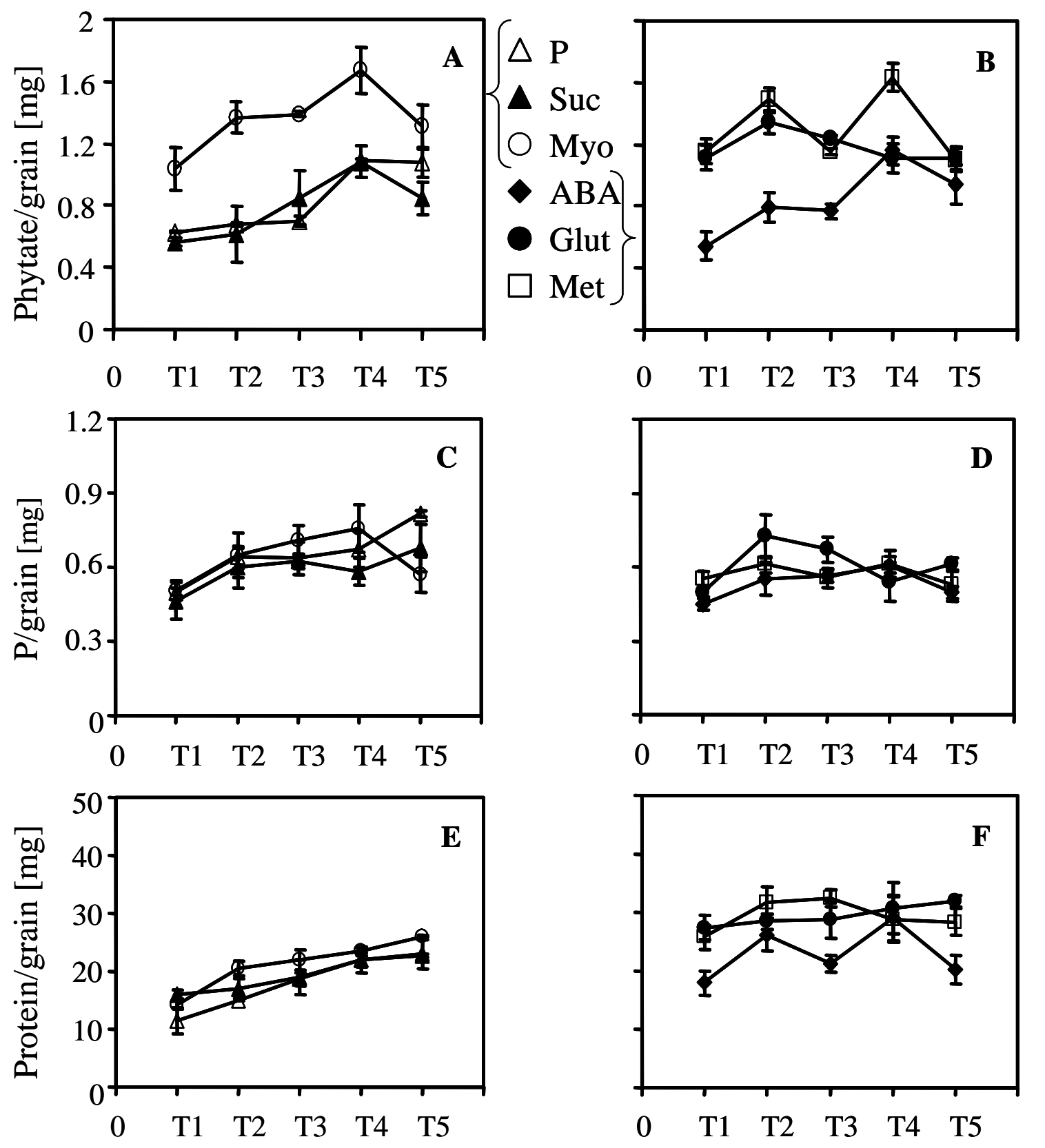

\section{Compounds concentration (mM)}

Figure 1- Phytic acid, phosphorus (P) and protein contents of common bean seed from fruit explants cultured for 12 days in basal medium amended with one of the following compounds at different concentrations: $\mathrm{P}(\triangle)(\mathrm{T} 1=0 \mathrm{mM}$ P; T2= $3 \mathrm{mM}$; T3= $6 \mathrm{mM}$; T4= $12 \mathrm{mM}$; T5= 24 $\mathrm{mM})$; glutamine $(\mathrm{O})(\mathrm{T} 1=0 \mathrm{mM} ; \mathrm{T} 2=10 \mathrm{mM} ; \mathrm{T} 3=20 \mathrm{mM} ; \mathrm{T} 4=40 \mathrm{mM} ; \mathrm{T} 5=80 \mathrm{mM})$; myo-inositol $(\mathrm{O})(\mathrm{T} 1=0 \mathrm{mM} ; \mathrm{T} 2=1 \mathrm{mM} ; \mathrm{T} 3=5 \mathrm{mM}$; T4= $10 \mathrm{mM}$; T5= $20 \mathrm{mM})$; abscisic acid $(-)$ ) $(\mathrm{T} 1=0 \mathrm{mM} ; \mathrm{T} 2=0.05 \mathrm{mM} ; \mathrm{T} 3=0.10 \mathrm{mM} ; \mathrm{T} 4=0.125 \mathrm{mM} ; \mathrm{T} 5=0.150 \mathrm{mM})$; methionine ( $\square$ ) $(\mathrm{T} 1=0 \mathrm{mM}$; T2= $5 \mathrm{mM}$; T3= $10 \mathrm{mM}$; T4= $15 \mathrm{mM}$; T5= $25 \mathrm{mM}$ ), and sucrose $(\Delta)(\mathrm{T} 1=0 \mathrm{mM} ; \mathrm{T} 2=40 \mathrm{mM} ; \mathrm{T} 3=80 \mathrm{mM} ; \mathrm{T} 4=160 \mathrm{mM} ; \mathrm{T} 5=320 \mathrm{mM})$. 

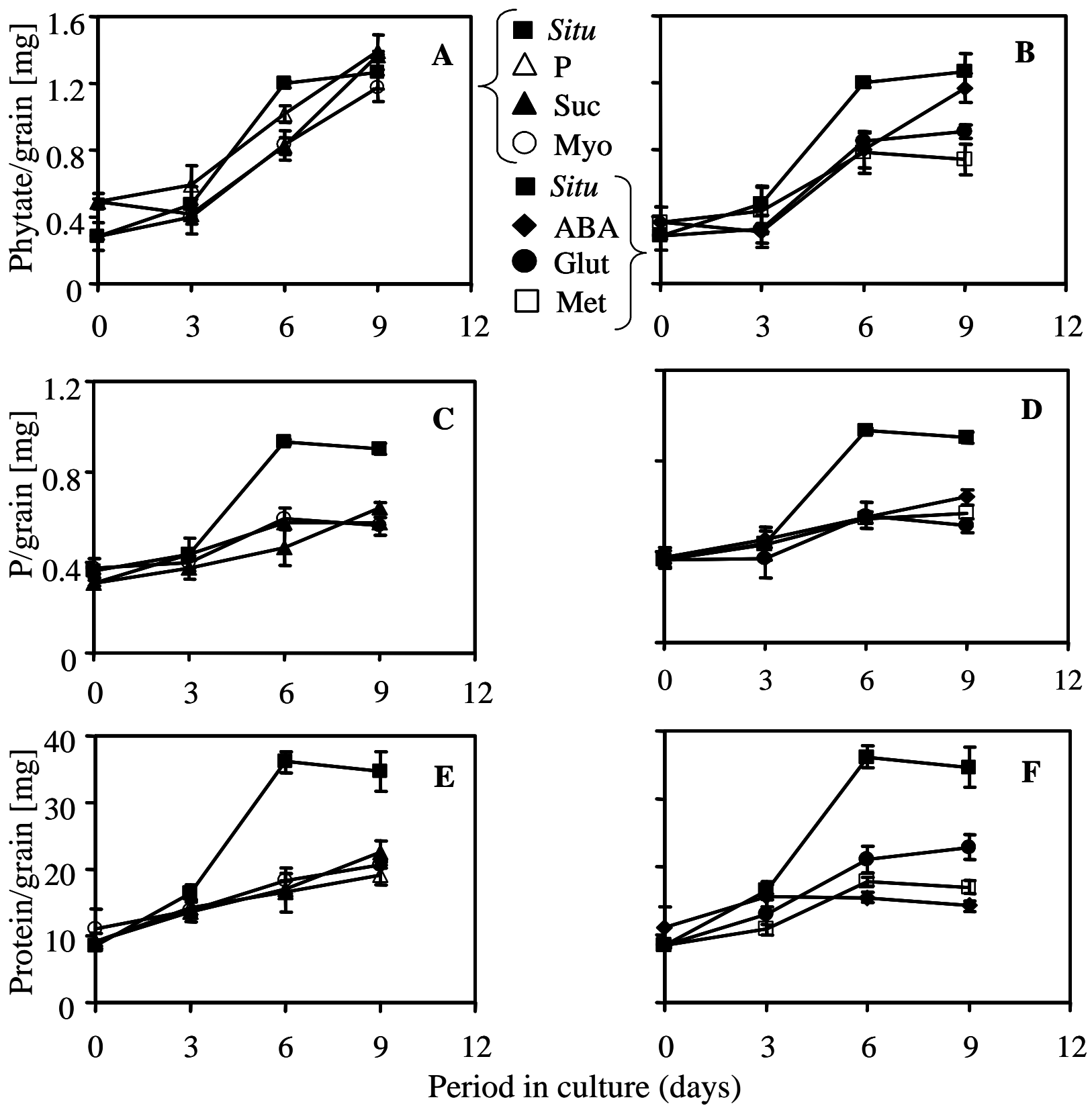

Figure 2 - Phytic acid, phosphorus (P) and protein contents of common bean seed from fruit explants cultured in medium basal amended with fixed concentration of compounds at: $12 \mathrm{mM}$ phosphorus $(\triangle) ; 80 \mathrm{mM}$ glutamine $(\bigcirc) ; 10 \mathrm{mM}$ myo-inositol $\bigcirc$ ); $0.125 \mathrm{mM}$ abscisic acid $(\Delta)$ ); $22 \mathrm{mM}$ methionine $(\square) 160 \mathrm{mM}$ sucrose ( $\boldsymbol{\Delta}$ ) and in situ culture ( $\boldsymbol{\square}$ ) for 0, 3,6 and 9 days. Bars indicate standard errors $(n=3)$.

Moreover, the relationship between phytate and $\mathrm{P}$ at a fixed concentration of $\mathrm{P}$ and myo-inositol during the growth period (Fig. 2A, C) revealed considerable alterations in the accumulation of phytate, but not of P. Likewise, at fixed concentrations, sucrose and ABA also caused alterations in the accumulation of phytate (Fig. 2A, $\mathrm{B}, \mathrm{C}, \mathrm{D})$. The content of $\mathrm{P}$ in common bean seeds was 2-fold higher as the concentration of available $\mathrm{P}$ in the culture medium increased (Fig. 1C). These results corroborated with in situ studies reported in the literature, which showed that an increase in the 
available $\mathrm{P}$ caused an increase of $\mathrm{P}$ in seeds, mainly in the phytate form (Coelho et al., 2002; Raboy and Dickinson, 1984; Raboy and Dickinson, 1993).

Seed proteins also increased with longer growth culture periods (Fig. 2E). This increase of 10 $\mathrm{mg} / \mathrm{seed}$ was low if the variations observed for the in situ growth period (9 days), which caused an increase of $25 \mathrm{mg} / \mathrm{seed}$, were considered (Fig. 2E). These results were supported by the dry matter value obtained for seeds from in vitro culture, which was $60 \%$ lower than that from in situ (Tables 1 and 2). Future studies should be conducted to measure the alteration of the protein synthesis in vitro through the analysis of the accumulation of stored proteins, or the total amino acid content (Mosquim and Sodek, 1991; Mosquim and Sodek, 1992), employing available proteomic and metabolomic techniques (Azevedo et al., 2004a; Azevedo et al., 2004b; Helm et al., 2004), which would allow a more comprehensive evaluation of phytate metabolism.

The results obtained with phytate, $\mathrm{P}$ and protein accumulation in grain using in vitro the conditions corroborated with the previous studies using in situ conditions and in vitro condition with radiolabeled precursors (Coelho et al., 2002a e 2002b; Coelho et al., 2005b). In conclusion, $\mathrm{P}$, sucrose, ABA and myo-inositol caused an increase of phytate in common bean seeds (variety Una), thus showing that it could be possible to alter the synthesis of phytate by culturing bean fruit explants in vitro. The results obtained from this study would be useful for future research aimed at analyzing the regulation of phytate synthesis in seeds, since contrasting growth culture conditions were conducted should be to evaluate the accumulation of phytate in seeds. To better understand the regulatory mechanisms of phytate synthesis, studies conducted to analyze MIPS expression and seed storage proteins that might be differentially expressed under contrasting conditions, through SDS-PAGE and bi-dimensional gel electrophoresis.

\section{ACKNOWLEDGEMENTS}

This work was financed by grants to R.A.A. from Fundação de Amparo à Pesquisa do Estado de São Paulo, Brazil (FAPESP 03/08888-9). R.A.A and C.M.M.C. wish to thank the Conselho Nacional de Desenvolvimento Científico e Tecnológico
(CNPq, Brazil) for the fellowships received.

\section{RESUMO}

O fósforo é armazenado na forma de fitato nas sementes, o qual forma complexos estáveis e insolúveis com minerais e proteínas, conferindo efeito antinutriente. A síntese de fitato foi estudada em cultivo de explantes de fruto de feijão in vitro sob diferentes concentrações de sacarose, fósforo (P), mio-inositol, ácido abscísico (ABA), glutamina e metionina. Fixada a concentração destes compostos, testou-se os diferentes tempos de cultivo $(0,3,6$ e 9 dias). A variação no acúmulo de fitato ocorreu na presença de sacarose, mio-inositol, $\mathrm{P}$ e ABA nas diferentes concentrações e tempos testados. O acúmulo mais efetivo de fitato ocorreu na presença de mioinositol e $\mathrm{P}$. $\mathrm{O}$ acúmulo de $\mathrm{P}$ variou menos do que fitato em todos os tratamentos. Em conclusão, $\mathrm{P}$, sacarose, ABA e mio-inositol causaram aumento no fitato acumulado nas sementes, mostrando que foi possível alterar a síntese de fitato em cultivo de explantes de fruto de feijão.

\section{REFERENCES}

Azevedo, R.A.; Damerval, C.; Lea, P.J.; Landry, J.; Bellato, C.M.; Meinhardt , L.W.; Le Guilloux, M.; Delhaye, S.; Toro, A.A.; Gaziola, S.A.; Varisi, V.A. and Gratão, P.L. (2004a), Endosperm protein synthesis and lysine metabolism in distinct opaque maize seed mutants. Funct. Plant Biol., 31, 339-348.

Azevedo, R.A.; Lea, P.J.; Damerval, C.; Landry, J.; Bellato, C.M.; Meinhardt, L.W.; Le Guilloux, M.; Delhaye, S.; Varisi, V.A.; Gaziola, S.A.; Gratão, P.L. and Toro, A.A. (2004b), Regulation of lysine metabolism and endosperm protein synthesis by the opaque-5 and opaque-7 maize mutations. J. Agric. Food Chem., 52, 4865-4871.

Barratt, D.H.P. (1986), In vitro pod culture of Pisum sativum. Plant Sci., 43, 223-228.

Bernhart, D.N. and Wreath, A.R. (1955), Colorimetric determination of phosphorus by modified phosphomolybdate method. Anal. Chem., 27, 440441. 
Chandler, P.M.; Higgins, T.J.V.; Randall, P.J. and Spencer, D. (1983), Regulation of legumin levels in developing pea seeds under conditions of sulfur deficiency. Rates of legumin synthesis and levels of legumin mRNA. . Plant Physiol., 71, 47-54.

Cheryan, M. (1980), Phytic acid interations in food systems. Crit. Rev. Food. Sci. Nutr., 13, 297-335.

Coelho, C.M.M.; Bellato, C.M.; Santos, J.C.P.; Ortega, E.M.M. and Tsai, S.M. (2007a), Effect of phytate and storage conditions on the development of the hard to cook phenomenon in common beans. J. Sci. Food Agric., in press., 87:1237-1243.

Coelho, C.M.M.; Santos, J.C.P.; Tsai, S.M. and Vitorello, V.A. (2002a), Seed phytate content and phosphorus uptake and distribution in dry bean genotypes. Braz. J. Plant Physiol. , 14, 51-58.

Coelho, C.M.M.; Tsai, S.M. and Vitorello, V.A. (2005b), Dynamics of inositol phosphate pools (tris-, tetrakis- and pentakisphosphate) in relation to the rate of phytate synthesis during seed development in common bean (Phaseolus vulgaris L.). J. Plant Physiol., 162, 1-9.

Coelho, C.M.M. and Vitorello, V.A. (2002b), Incorporação de [14C]-sacarose e [3H]-mio-inositol em fosfatos de inositol via explantes de frutos de feijão (Phaseolus vulgaris). In: XI Reunion Latinoamericana de Fisiologia Vegetal, Punta del Este-Uruguai, Anais. Punta del Este-Uruguai. Ediciones del Copista: Cordoba Argentina, Oct. p.197.

Coelho, C.M.M.; Benedito, V.A.; Figueira, A.; Vitorello, V.A.; Azevedo, R.A. (2007b), Variation in the enzyme activity and gene expression of myoinositol-3-phosphate synthase (MIPS) and phytate accumulation during seed development in common bean (Phaseolus vulgaris L.). Acta Physiol. Plant., 29, 265-271.

Hegeman, C.E.; Good, L.L. and Grabau, E.A. (2001), Expression of D-myo-inositol-3-phosphate synthase in soybean. Implications for phytic acid biosynthesis. Plant Physiol., 125, 1941-1948.

Helm, C.V.; De Francisco, A.; Gaziola, S.A.; Fornazier, R.F.; Pompeu, G.B. and Azevedo, R.A. (2004), Hullless barley varieties: storage proteins and amino acid distribution in relation to nutritional quality. Food Biotechnol., 18, 327-341.

Larson, S.R.; Young, K.A. and Cook, A. (1998), Linkage mapping of two mutations that reduced phytic acid content of barley grain. Theor. Appl. Genet., 97, 141-146.

Latta, M. and Eskin, M. (1980), A simple method for phytate determination. J. Agric. Food Chem., 28, 1313-1315.

Loewus, F.A. and Murthy, P.P.N. (2000), Myo-inositol metabolism in plants. Plant Sci., 150, 1-19.
Lott, J.N.A.; Randal, P.J.; Goodchild, D.J. and Craig, S. (1985), Occurrence of globoid crystals in cotyledonary bodies of Pisum sativum as influenced changes in experimentally induced changes in $\mathrm{Mg}, \mathrm{Ca}$ and K contents of seeds. Aust. J. Plant Physiol., 12, 341-353.

Lucca, P.; Hurrell, R. and Potrykus, I. (2001), Genetic engineering approaches to improve the bioavailability and the level of iron in rice grains. Theor. Appl. Genet., 102, 392-397.

Mosquim, P.R. and Sodek, L. (1991), Culture of soybean fruit explants: growth conditions and efficiency of nitrogen sources for reserve protein synthesis. Plant Cell Tiss. Org. Cult., 27, 71-76.

Mosquim, P.R. and Sodek, L. (1992), Partitioning of nitrogen in soybean fruit explants cultured with glutamine, asparagine or allantoin. Plant Physiol. Biochem., 30, 451457.

Murashige, T. and Skoog, R. (1962), A revised medium for rapid growth and bioassays with tobacco tissue cultures. Physiol. Plant., 15, 473-497.

Parkinson, M. and Allen, N. (1975), Wet oxidation procedure suitable for determination of nitrogen and mineral nutirents in biological material. Communin. Soil Sci. Plan, 6, 1-11.

Raboy, V. (1990), The biochemistry and genetics of phytic acid synthesis in higher plants. In: Morre, E.J.; Boss, W.S. and Loewus, F.A. Inositol metabolism in plants. New York: John Wiley and Sons, 1, cap. pp.55-76.

Raboy, V. and Dickinson, D.B. (1984), Effect of phosphorus and zinc nutrition on soybean seed phytic acid and zinc. Plant Physiol., 75, 1094-1098.

Raboy, V. and Dickinson, D.B. (1993), Phytic acid levels in seeds of Glycine max and G. Soja as influenced by phosphorus status. Crop Sci., 33, 1300-1305.

Raboy, V.; Gerbasi, P.F.; Young, K.A.; Stoneberg, S.D.; Pickett, S.G.; Bauman, A.T.; Murthy, P.P.N.; Sheridan, W.F. and Ertl, D.S. (2000), Origin and Seed Phenotype of Maize low phytic acid 1-1 and low phytic acid 2-1. Plant Physiol., 124, 355-368.

Raboy, V.; Young, K.A.; Dorsch, J.A. and Cook, A. (2001), Genetics and breeding of seed phosphorus and phytic acid. J. Plant Physiol., 158, 489-497.

Reddy, N.R.; Pierson, M.D.; Sathe, S.K. and Salunkhe, D.K. (1989), Phytates in cereals and legumes. Boca Raton: CRC Press, 152pp.

Shi, J.R.; Wang, H.Y.; Wu, Y.S.; Hazebroek, J.; Meeley, R.B. and Ertl, D.S. (2003), The maize lowphytic acid mutant $1 \mathrm{pa} 2$ is caused by mutation in an inositol phosphate kinase gene. Plant Physiol., 131, 507-515.

Stevenson-Paulik, J.; Odom, A.R. and York, J.D. (2002), Molecular and biochemical characterization of two plant inositol polyphosphate 6-/3-/5-kinases. J. Biol. Chem., 277, 42711-42718. 
Yoshida, K.T.; Wada, T.; Koyama, H.; MizobuchiFukuoka, R. and Naito, S. (1999), Temporal and spatial patterns of accumulation of the transcript of myo-inositol-1-phosphate synthase and phytincontaining particles during seed development in rice. Plant Physiol., 119, 65-72.

Yoshida, K.T.; Fujiwara, T. and Naito, S. (2002), The synergistic effects of sugar and abscisic acid on myoinositol-1-phosphate synthase expression. Physiol. Plant., 114, 581-587.
Zhou, J.R. and Erdman, J.W. (1995), Phytic acid in health and disease. Crit. Rev. Food. Sci. Nutr., 35, 495-508.
Received: March 02, 2006; Revised: October 04, 2006; Accepted: July 09, 2007. 